\title{
Some solutions for sustainable agricultural tourism development in the Mekong Delta in Vietnam
}

\author{
Bao Hoang Gia \\ Language Department, FPT University, Vietnam
}

\begin{abstract}
Agricultural tourism is a current trend in the Mekong Delta of Vietnam need to exploit and it is necessary to take advantages of the natural advantages to exploit key trends such as authentic cultural experiences, ecotourism, agricultural tourism, healthcare, etc. In recent years, agricultural tourism products have been the main attraction and these products can promote both domestic and international tourist growth. With many tourism products bearing the cultural characteristics of the region is known, stretching from North to South in general and in the Mekong delta in particular, agro-tourism has brought increasingly clearer socio-economic effects, contributing to the abundance and attractiveness of tourism products, and at the same time improving high levels of income for farmers. This paper focuses on analyzing the advantages as well as disadvantages and from there proposing some solutions for the most practical agricultural tourism in this area.
\end{abstract}

\section{Introduction}

Surrounded by the river branches (Tien and Hau rivers) of 4 provinces (Tien Giang, Ben Tre, Vinh Long and Tra Vinh province) with an area of about $8,618 \mathrm{~km} 2$, has a coastline of $162 \mathrm{~km}$, Mekong Delta is the largest agricultural region and one of the seven tourist regions of Vietnam. This place is considered the "rice bowl", "fruit garden" or "shrimp and fish field" of the country.

Moreover, the gentle river landscape, friendly people and hospitable people are also favorable conditions for agricultural tourism development. Currently, in the provinces of Tien Giang, Ben Tre, Vinh Long, Tra Vinh, many agricultural tourist sites have been formed, visitors can play the role of a farmer picking fruit, gardening, and resting at the local people's house [1].

In addition, visitors also have the opportunity to visit traditional craft villages, bakeries or visit traditional floating markets including Cai Be floating market, Cai rang floating market, etc. This model has initially brought in the positive effect, creating more sources of income for farmers, stimulating creativity in economic activities and business in rural areas [2]. The Mekong Delta is close to major cities of which the city is located. Can Tho city and neighboring provinces, which is the largest tourism market of Vietnam. Currently, the traffic network is being upgraded and newly built, therefore more than a quarter of the area is within a radius of 1-2 hours by car, from the city. Ho Chi Minh. These will be favorable conditions for the sub-region.

\section{The current situation of tourists}

\footnotetext{
* Corresponding author: thaonguyendong158@gmail.com
}

\subsection{The number of international tourists to Vietnam}

Agricultural ecotourism products in Vietnam only meet the needs of visitors to visit, rest, and eat at a simple level. Most of the current agricultural tourism activities in Vietnam in general and the Mekong River Delta are still spontaneous, small, duplicated, the product is not really attractive to tourists and has not been focused on the brand [3]. Tourists come here still do not have diversity. According to online newspaper of the Vietnamese government, most of them are still tourists from Asia such as China and Korea. The attractiveness of tourists from Europe and other regions is still limited and has a hidden potential (Figure 1).

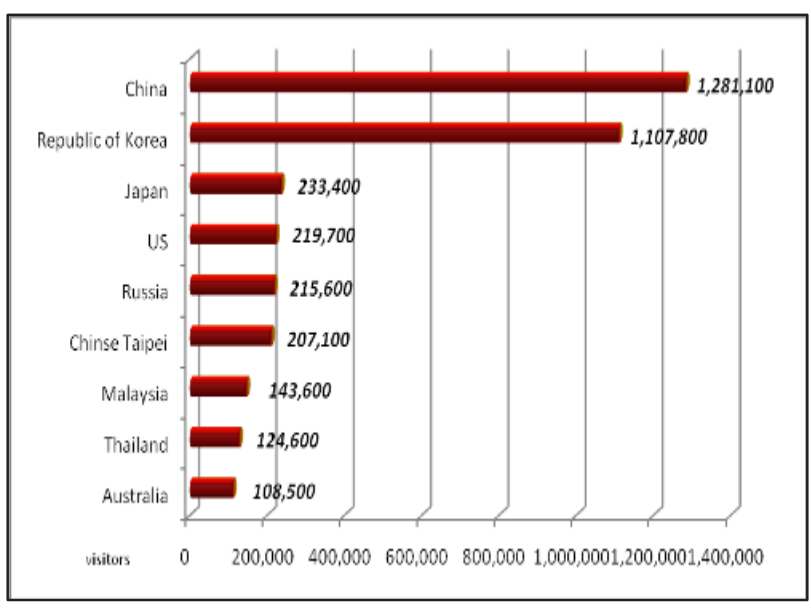

Figure 1. The number of visitors to Viet Nam in the first quarter of 2019 by air and road 
A lot of farmers are only accustomed to agricultural production, do not have the skills to professionally serve tourists, or are not interested in or set production targets associated with tourism development. Infrastructure and supporting facilities at many agro-eco-tourist sites have not been invested completely and of low quality [4].

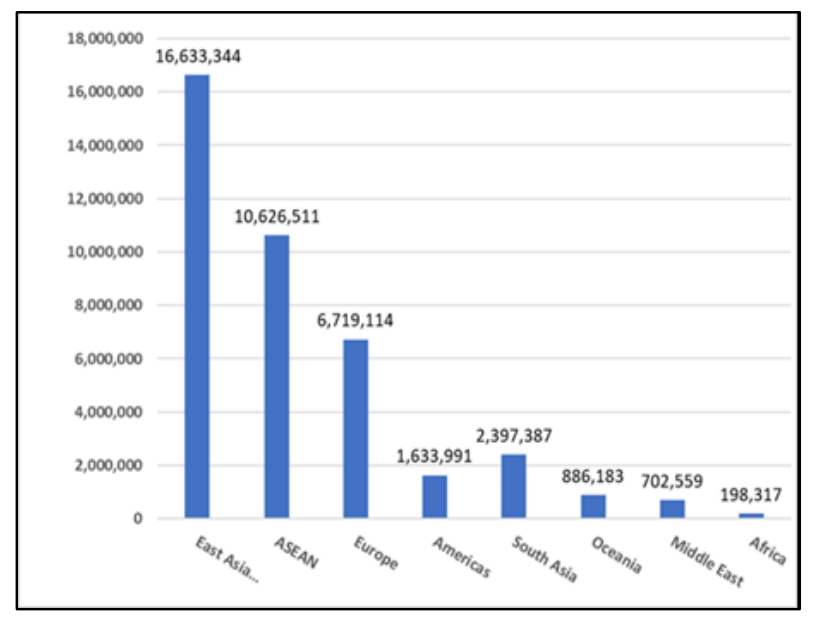

Figure 2. International Visitors to Thailand in 2019

In 2018, the Mekong Delta welcomed 40,745,296 tourists to visit, up $16.8 \%$ over the same period. In which, there were $3,420,109$ international visitors, up $19.8 \%$ over the same period, reaching revenue of 23,782.7 billion dong, up 38\% over the same period in 2017. Among localities in the region, Soc Trang, Hau Giang, Kien Giang are typical localities with an impressive increase in arrivals. The locality that attracts the most tourists to visit is An Giang with 8.5 million visitors, mainly festival visitors. The locality that attracts the most international visitors is Tien Giang with 811,249 arrivals and the locality with the highest tourism revenue is Kien Giang province with 6,195 billion VND.

Agricultural tourism is becoming a new direction of many rural areas, bringing positive economic effects, contributing to improving the lives of people, helping many rural areas to develop much more than usual, shortening the way to catch up with other cities [5]. By combining production with attractions, tourism, and experiences, homeowners can increase their profits by 2 to 3 times compared to just producing and consuming products. In the total income of rural people today, income from agricultural production only accounts for $27 \%$, income from non-agricultural production activities and services accounts for $73 \%$.

However, when comparing the numbers of tourists with neighboring countries, namely Thailand, Vietnam still reveals many shortcomings and needs more attention (Figure 2).

\section{Potential and current status of agricultural tourism development in the Mekong Delta}

In the Vietnam Tourism Development Strategy to 2020, a vision to 2030 also states that the typical products of the Mekong Delta are ecotourism, exploitation of river cultural values, horticulture, relaxation, marine ecology, islands, etc. ". Accordingly, the Tourism Development Project for the Mekong Delta region up to 2020 has been divided into 4 tourist clusters, of which the central cluster includes the city. Can Tho, An Giang, Kien Giang and Hau Giang with outstanding products are river tourism, festival tourism, tourism for commercial purposes, luxury sea resorts.

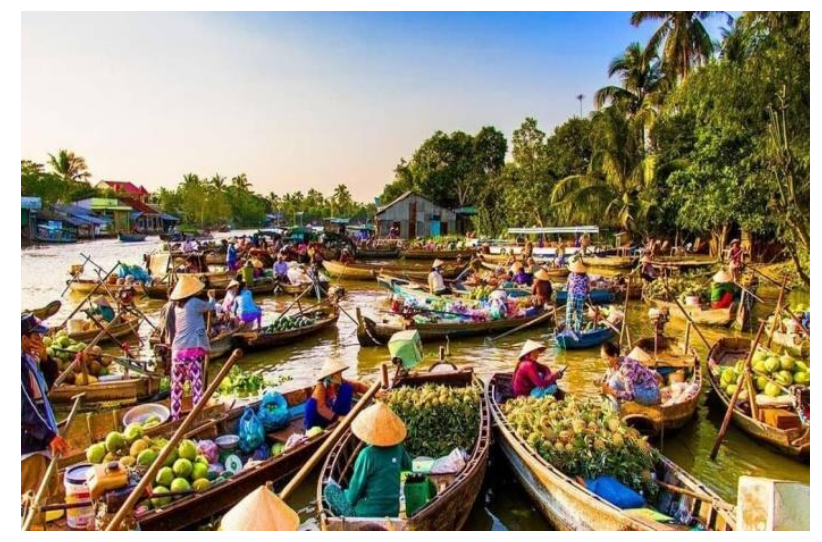

Figure 3. Floating markets in Mekong delta

The type of agri-tourism in the Mekong Delta develops in parallel with the community-based tourism, ecotourism and is all linked to agriculture and rural areas.

Each locality has taken good advantage of comparative advantages to develop tourism associated with sustainable agriculture, associated with traditional craft villages [6]. These include farming tours, visiting vegetable gardens, flowers, experiencing hi-tech agricultural production, visiting orchards, craft villages, flower villages, floating markets, etc. (Figure 3).

The agro-tourism type in the Eastern coastal subregion of the Mekong Delta develops in parallel with the community-based tourism, ecotourism and is all associated with agriculture and rural areas [7]. Each locality has taken good advantage of comparative advantages to develop tourism associated with sustainable agriculture, associated with traditional craft villages [5]. These include agricultural tours, vegetable garden tours, experience in hi-tech agricultural production, fruit orchards, craft villages, flower villages, etc.

Although the agricultural tourism activities of the eastern coastal region of the Mekong Delta have improved significantly, but not as expected. One of the main reasons is that the agricultural tourism products of the Mekong Delta are duplicated, lack of uniqueness, the uniqueness of the tour development, tourism routes, etc. Visitors come and go mainly during the day Short stay, little spending, low revenue [8]. Meanwhile, the link between localities has not been tight, making the region's tourism potential not adequately exploited.

In addition, agricultural tourism still has a number of limitations and challenges that need to be overcome such as the spontaneous development of agricultural tourism in some localities; the human resource is insufficient and weak; have not attracted much investment capital [9]. To 
get profits from this tourism model, it is very necessary to have the orientation of the management agencies, the cooperation of agricultural enterprises and especially the entry of tourism companies. Tourism products are still overlapping and do not have certain diversity (Figure 4).

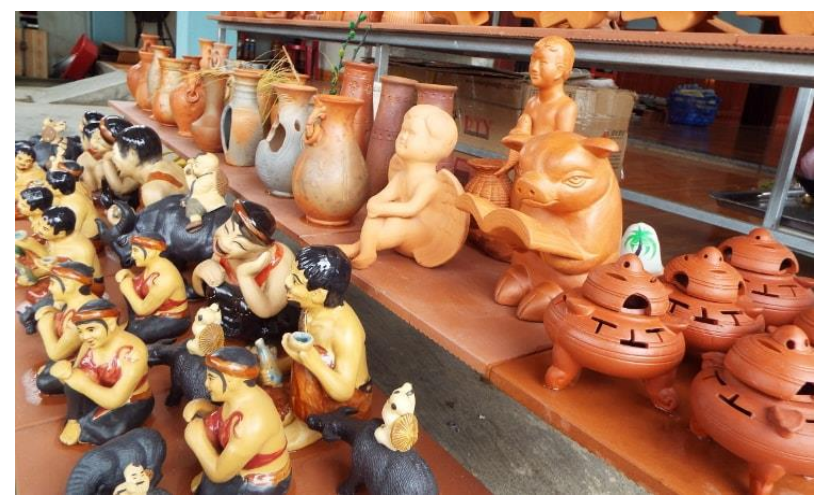

Figure 4. Handicrafts made in Mekong Delta

\section{Development direction in the future}

Agricultural tourism is gradually becoming a "strange food", besides the types of resort tourism, spiritual cultural tourism, discovery, etc., which are the strengths of tourism in the coastal sub-region. East of the Mekong Delta. Farmers have the opportunity to promote agricultural products and increase their income, contributing to promoting sustainable socio-economic development [4]. To develop this type of tourism sustainably, please propose a number of solutions to develop agricultural tourism in the eastern coastal subregion of the Mekong Delta in the integration period.

First, developing tours in association with agriculture. In the immediate future, we need to mobilize individuals, agricultural production organizations, tourism businesses, travel businesses, and local authorities to implement a number of models, open tours, routes and orchards, visiting agricultural cultivation, visiting traditional craft villages, hi-tech agricultural production zones of Tien Giang, Ben Tre, Tra Vinh and Vinh Long (Figure 5).

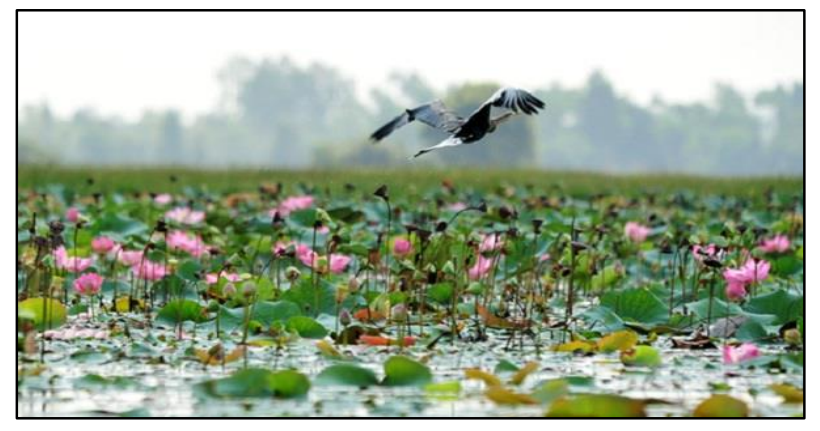

Figure 5. Lotus field in Mekong delta

Second, the subregion's local leaders need to increase the linkage between state management agencies, farmers, scientists, and travel businesses. Strengthen propaganda and promotion; promote investment promotion and tourism promotion [9]. To adopt a new rural development policy associated with economic development of tourism for organizations, individuals and enterprises that implement the agricultural tourism model. At the same time, training human resources for selected agricultural tourism models, encouraging farmers to participate in parallel with improving the quality of each tourist destination.

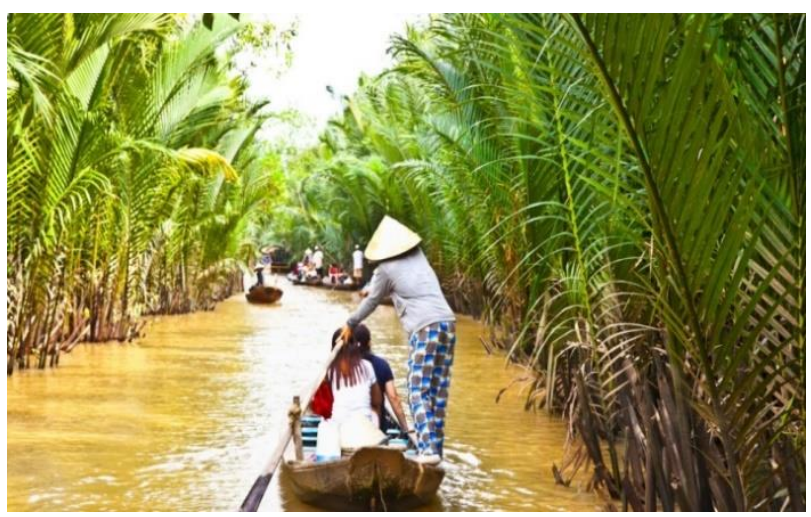

Figure 6. Travel through small canals in Mekong delta

Second, the local leaders of the sub-region need to increase the linkage. Third, build a set of criteria for agricultural and fishery production establishments to meet the standards of tourism development associatedwith agriculture: Green, clean, secure and safe, food hygiene and safety (no chemicals are used in production). To do this, concerned departments and branches need to guide farmers in developing hi-tech agriculture, becoming a tourist destination [4]. In addition, it allows visitors to join farmers in harvesting, planting and tending crops in the fields, helping them relax, entertain, exercise, be close to nature and experience farm life (Figure 6).

Fourth, there should be solutions to train farmers with basic knowledge of tourism in order to improve the quality of service to tourists. Well developing this type of tourism is an opportunity to create jobs, empower local communities, etc. In addition, to develop agricultural tourism, it is certainly indispensable for the role of travel businesses. They will make a significant contribution to "blowing souls" in the stages of creating new and attractive agricultural tourism products.

Fifth, develop tourism model associated with agricultural development in a sustainable way [9]. Farmers need to consciously protect their landscape and living environment and ensure food hygiene and safety. At the same time, it is necessary to pay attention to exploit the available local resources.

State management agencies, farmers, scientists, travel businesses. Strengthen propaganda and promotion; promote investment promotion and tourism promotion. To adopt a new rural development policy associated with tourism economic development for organizations, individuals and enterprises that implement the agricultural tourism model. At the same time, training human resources for selected agricultural tourism models, encouraging farmers to participate in parallel with improving the quality of each tourist destination [10]. 


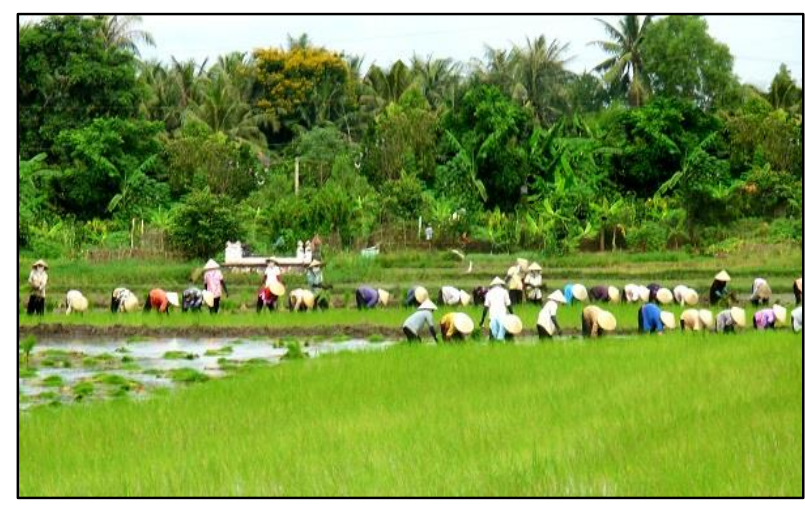

Figure 7. Paddy field in Mekong Delta

Sixthly, it is necessary to build a number of tourism products associated with agriculture on the basis of exploiting specific strengths of each locality in the common cultural space, avoiding duplication or copying from other localities [8]. To do so, it is necessary to perfect the agricultural tourism development planning from the state management level; increase the construction of transport infrastructure, agricultural facilities; step up the training of human resources for tourism businesses and equip farmers with tourism knowledge [11]. At the same time, management levels call for investment in construction and development of hi-tech agricultural zones and farms in accordance with international standards; strengthen market expansion and propaganda for rural tourism programs towards sustainability (Figure 7).

Seventh, branding for agricultural tourism in the eastern coastal region of the Mekong Delta on the basis of regional characteristics, agricultural seasons, and local products. It is necessary to develop an agricultural tourism map, increase the exploitation of effective modern information and communication technology to promote agricultural tourism.

\section{Conclusion}

Although the agricultural tourism activities of the eastern coastal region of the Mekong Delta have improved significantly, but not as expected. One of the main reasons is that the agricultural tourism product of the Mekong Delta is not unique, not specific in the development of tours, routes, etc. Visitors come and go mainly within the day, short stay time, little spending. low sales; At the same time, the link between localities is not really close, making the region's tourism potential not adequately exploited. To continue to effectively exploit agricultural tourism in the eastern coastal region of the Mekong Delta, the Government, ministries, central agencies and localities need to soon develop an agricultural tourism development strategy in line with the trend of import, with the particularities and capabilities of each locality. On that basis, the Party committees and authorities at all levels study and propose policies to encourage all economic sectors to join in investing in developing agricultural tourism; to soon form a chain of cooperation links between localities. At the same time, building and implementing programs on agricultural tourism development associated with new rural construction; maximizing the characteristics of agriculture combined with cultural values, contributing to the breakthrough, efficiency and sustainable development of agricultural tourism.

\section{Ethical clearance}

I am ensuring the quality and integrity of our research. The ideas and opinions expressed in this paper are of my effort. By writing this research paper, I surely respect the confidentiality and anonymity of my research respondents since they participated in my work voluntarily.

\section{Source of funding}

The author would like to send the warm thanks to Ho Chi Minh City Open University, Vietnam for the financial support.

\section{References}

1. Szabo, S., Renaud, F. G., Hossain, M. S., Sebesvári, Z., Matthews, Z., Foufoula-Georgiou, E., \& Nicholls, R. J. Sustainable development goals offer new opportunities for tropical delta regions. Environment: Science and Policy for Sustainable Development, 57, 4 (2015).

2. Estellès, P., Jensen, H., Sánchez, L., \& Vechiu, G. Sustainable development in the Mekong Delta. Centre for Environmental Studies, University of Aarhus (2002).

3. Hanh, V. T. H. Canal-side highway in Ho Chi Minh City (HCMC), Vietnam-Issues of urban cultural conservation and tourism development. GeoJournal, 663 (2006).

4. Huu, L. H., Ballatore, T. J., Irvine, K. N., Nguyen, T. H. D., Truong, T. C. T., \& Yoshihisa, S. Sociogeographic indicators to evaluate landscape Cultural Ecosystem Services: A case of Mekong Delta, Vietnam. Ecosystem Services, 31 (2018).

5. Lensink, R., \& Nam, M. V. Economic development of the Mekong Delta in Vietnam. CDS Research paper, 27 (2008).

6. Hoi, H. T. Advertising Vietnam's Tourism Products in the Technology Age. In Proceedings of the 2020 International Conference on Management of eCommerce and e-Government, (2020).

7. Hieu, V. M., Vu, N. M., \& Nwachukwu, C. Exploring human resources, marketing and promotion activities towards the sustainable tourism development in Phu Quoc islands, Vietnam. Management, 241 (2020).

8. Doan, N. T. K. Sustainable tourism development in Vietnam. Linking Green Productivity to Ecotourism: Experiences in the Asia-Pacific Region. Tokyo: Asian Productivity Organization Publication, (2010).

9. Hau, P., \& Tuan, V. A. The development of rural tourism in Vietnam: objectives, practical experiences and challenges. Van Hien University Journal of Science, 52 (2017).

10. Laws, E., \& Semone, P. The Mekong: Developing a new tourism region. River tourism, (2009).

11. Hoi, H. T. Some Recommendations to Attract Japanese Tourists to Vietnam. Test Engineering and Management, 82, (2020). 